\title{
PERANAN ALAT BUKTI DALAM HUKUM ACARA PERADILAN
}

\author{
Asep Saepullah \\ Fakultas Syariah dan Ekonomi Islam \\ Institut Agama Islam Negeri Syekh Nurjati Cirebon \\ Email: Seppullah@yahoo.com
}

\begin{abstract}
ABSTRAK
Sistem hukum pembuktian yang dianut di Indonesia adalah sistem tertutup dan terbatas dimana para pihak tidak bebas mengajukan jenis atau bentuk alat bukti dalam proses penyelesaian perkara. Undang-undang telah menentukan secara tegas apa saja yang sah dan bernilai sebagai alat bukti. Pembatasan kebebasan juga berlaku bagi hakim dimana hakim tidak bebas dan leluasa menerima apa saja yang diajukan para pihak sebagai alat bukti. Apabila pihak yang berperkara mengajukan alat bukti diluar ketentuan yang ada didalam undang-undang yang mengatur, hakim harus menolak dan mengesampingkanya dalam penyelesaian perkara. Dalam proses perkara dari kelima alat bukti yang dapat diajukan, alat bukti tertulis merupakan alat bukti yang di utamakan, karena karakteristik perkara dan perbuatan hukum sendiri yang bersifat formil. Segala perbuatan hukum yang formil yang dituangkan secara tertulis yang dilakukan secara terang dan konkrit agar dapat mewujudkan hukum acara perdata sebagaimana yang diatur dalam Kitab Undang-Undang Hukum Perdata dan agar memberikan kekuatan hukum untuk menjamin hak-hak yang dimiliki seseorang.
\end{abstract}

Kata Kunci: Alat Bukti, Hukum Acara Peradilan, dan Hakim

\begin{abstract}
The legal system of evidence established in Indonesia is a closed and limited system in which the parties are not free to submit any type or form of evidence in the settlement process of the case. The law has clearly defined what is legitimate and valuable as evidence. The limitation of freedom also applies to judges in which the judge is not free and freely accepts whatever the parties have proposed as evidence. If the litigant submits evidence outside the provisions contained in the regulating law, the judge shall refuse and dismiss him in the settlement of the case. In the case process of the five evidences that can be submitted, written evidence is the preferred means of evidence, because the character of the case and the legal act itself is formal. Any formal legal action expressed in writing which is done in a clear and concrete manner in order to realize the law of civil procedure as stipulated in the Civil Code and in order to provide the legal force to guarantee the rights of a person.
\end{abstract}

Keywords: Evidence Instrument, Judicial Procedure Law, and Judge 
A. Pendahuluan

Pembuktian tentang benar
tidaknya terdakwa melakukan
perbuatan yang didakwakan
merupakan bagian yang terpenting
dalam acara pidana, dimana hak asasi
manusia dipertaruhkan. Bagaimana
akibatnya jika seorang yang didakwa
dinyatakan terbukti melakukan
perbuatan yang didakwakan
berdasarkan alat bukti yang ada
disertai keyakinan Hakim, padahal
tidak benar.

Berkaitan dengan pembuktian Hukum Acara Pidana mengenal asasasas yang menjadi dasar pemeriksaan, yaitu asas praduga tak bersalah dan asas kebenaran materiil. Hal ini menjadi dasar pemeriksaan karena untuk melindungi hak asasi manusia yang dimiliki setiap orang. ${ }^{2}$

Setiap orang yang terlibat dalam perkara pidana harus dianggap belum bersalah sebelum adanya putusan pengadilan yang menyatakan kesalahan itu, asas ini disebut asas praduga tak bersalah. Asas kebenaran materiil adalah suatu asas yang menghendaki bahwa dalam pemeriksaan perkara pidana lebih mementingkan pada penemuan kebenaran materiil (materiale warheid) yakni kebenaran yang sesungguhnya sesuai kenyataan. ${ }^{3}$ Seperti halnya pembuktian ada untuk mendapatkan kebenaran yang sebenarbenarnya dalam peradilan.

Pembuktian dalam Hukum Acara Pidana adalah suatu upaya mendapatkan keterangan-keterangan melalui alat-alat bukti dan barang bukti, guna memperoleh suatu keyakinan atas benar tidaknya

1 Andi Hamzah, Hukum Acara Pidana Indonesia, (Jakarta: Sinar Grafika, 2008), . 249

2 Tri Andrisman, Hukum Acara Pidana, (Bandarlampung: Penerbit Universitas Lampung, 2010), . 14

${ }^{3}$ Tri Andrisman, Hukum Acara Pidana, . 15 perbuatan pidana yang didakwakan serta dapat mengetahui ada tidaknya kesalahan pada diri terdakwa.4 Untuk kepentingan pembuktian tersebut maka sangat diperlukan kehadiran benda-benda yang berkaitan dengan suatu tindak pidana, lazimnya bendabenda tersebut disebut sebagai "Barang Bukti".

Barang bukti yang bukan merupakan obyek, barang bukti atau hasil delik tetapi dapat pula dijadikan barang bukti sepanjang barang bukti tersebut mempunyai hubungan langsung dengan tindak pidana, misalnya uang yang dipakai korban pada saat ia melakukan kejahatan korupsi bisa dijadikan barang bukti. Selanjutnya, benda sitaan mempunyai peranan yang sangat penting dalam proses pidana, walaupun semua aturan yang ada tidak ada satu pasalpun yang memberikan definisi atau pengertian mengenai benda sitaan secara implisit (tersirat) ataupun secara nyata. ${ }^{4}$

Barang bukti adalah hasil serangkaian tindakan penyidik dalam penyitaan, dan atau penggeledahan dan atau pemeriksaan surat untuk mengambil alih dan atau menyimpan dibawah penguasaannya benda bergerak atau tidak berwujud untuk kepentingan pembuktian dalam penyidikan, penuntutan dan peradilan. $^{5}$

\section{B. Pembahasan}

\section{Pengertian dan Dasar Hukum Pembuktian}

Pembuktian di muka pengadilan adalah merupakan hal yang terpenting dalam hukum acara karena pengadilan dalam

4 Andi Hamzah, Kamus Hukum, (Jakarta: Ghalia, 2006), .100

5 Hari Sasangka dan Lily Rosita, Hukum Pembuktian dalam Perkara Pidana, (Bandung, Mandar Maju, 2003), . 99 
menegakkan hukum dan keadilan tidak lain berdasarkan pembuktian. Hukum pembuktian termasuk dari bagian hukum acara sedangkan Peradilan Agama mempergunakakan hukum acara yang berlaku bagi Peradilan Umum. ${ }^{6}$

Menurut R. Subekti dalam Manan, ${ }^{7}$ yang dimaksud dengan pembuktian adalah suatu daya upaya para pihak yang berperkara untuk meyakinkan hakim tentang kebenaran dalil-dalil yang dikemukakannya di dalam suatu perkara yang sedang dipersengketakan di muka pengadilan, atau yang diperiksa oleh hakim. Sedangkan menurut Manan, ${ }^{8}$ pengertian pembuktian adalah upaya para pihak yang berperkara untuk meyakinkan hakim akan kebenaran peristiwa atau kejadian yang diajukan oleh para pihak yang bersengketa dengan alat-alat bukti yang telah ditetapkan UU.

Adapun menurut Achmad Ali, ${ }^{9}$ pembuktian adalah upaya yang dilakukan oleh para pihak untuk menyelesaikan persengketaan mereka atau untuk member kepastian tentang peristiwa hukum tertentu, dengan menggunakan alat bukti yang ditentukan hukum, sehingga dapat dihasilkan suatu penetapan atau putusan pengadilan.

Pembuktian merupakan salah satu rangkaian tindakan

6 Roihan A. Rasyid, Hukum Acara Peradilan Agama, (Jakarta: Raja Grafindo Persada, 2006), . 143.

7 Abdul Manan, Penerapan Hukum Acara Perdata di Lingkungan Peradilan Agama, cet. ke-5, (Jakarta: Kencana, 2008), . 227

8 Abdul Manan, Penerapan Hukum Acara Perdata di Lingkungan Peradilan Agama, . 227

9 Achmad Ali dan Wiwie Heryani, AsasAsas Hukum Pembuktian Perdata, (Jakarta: Kencana, 2012), . 21. hakim dalam melaksanakan tugas pokok pemeriksaan perkara yaitu mengonstatir perkara. Adapun tugas pokok hakim dalam pemeriksaan perkara yang dilakukan secara berurut dan sistematis, yaitu: pertama mengonstatir perkara yaitu melihat benar tidaknya peristiwa dan faktafakta yang diajukan pihak-pihak yang berperkara, sebagaimana halnya pembuktian. Kedua, mengualifisir peristiwa yang telah dikonstatir hukumnya atau mengadili menurut hukum dan yang ketiga, menetapkan dan menerapkan hukumnya untuk keadilan. ${ }^{10}$

Pembuktian merupakan kekuatan-kekuatan yang berisi penggarisan dan pedoman tentang tata cara yang dibenarkan undangundang membuktikan kesalahan yang didakwakan kepada terdakwa. Pembuktian juga merupakan ketentuan yang mengatur alat-alat bukti yang dibenarkan undangundang dan yang boleh dipergunakan oleh Hakim membuktikan kesalahan yang didakwakan. ${ }^{11}$

Adapun arti membuktikan yaitu memberi dasar-dasar yang cukup kepada hakim yang memeriksa perkara yang bersangkutan guna memberi kepastian tentang kebenaran peristiwa yang diajukan. ${ }^{12}$

Asas hukum pembuktian ini diatur dalam Pasal 163 HIR atau

10 Aris Bintania, Hukum Acara Peradilan Agama dalam Kerangka Fiqh al-Qadha, (Jakarta: Raja Grafindo Persada, 2012), . 53-54.

11 Yahya Harahap, Pembahasan Permasalahan dan Penerapan KUHAP, Jilid 2, (Jakarta: Sinar Grafika, 1993), . 793

12 Sudikno Mertokusumo, Hukum Acara Perdata Indonesia, Edisi Revisi, (Yogyakarta: Cahaya Atma Pustaka, 2013), . 144. 
Pasal $283 \mathrm{RBg}$ yang berbunyi: "Barang siapa yang mengatakan ia mempunyai hak, atau ia menyebutkan sesuatu perbuatan untuk menguatkan haknya itu, atau untuk membantah hak orang lain, maka orang itu harus membuktikan adanya hak itu atau adanya kejadian itu."13 Inti pokok dari pernyataan di atas dapat dirinci sebagai berikut:

a. Pihak yang mengatakan mempunyai hak harus membuktikan haknya tersebut.

b. Pihak yang menyebutkan suatu peristiwa untuk meneguhkan haknya harus membuktikan adanya peristiwa tersebut.

c. Pihak yang menyebutkan suatu peristiwa untuk membantah hak orang lain harus membuktikan adanya peristiwa tersebut. ${ }^{14}$

Praktik substansi asas pembuktian ini diterapkan secara selektif dalam proses peradilan. Dalam artian, tidak semua faktafakta hukum harus dibuktikan di persidangan. Adapun fakta-fakta hukum yang tidak harus dibuktikan di persidangan mencakup mengenai hal-hal:

a. Apabila pihak tergugat/para tergugat mengakui kebenaran surat gugatan penggugat atau para penggugat.

b. Apabila pihak tergugat/para tergugat tidak menyangkal surat gugatan penggugat atau para penggugat karena dianggap mengakui kebenaran surat tersebut.

${ }^{13}$ M. Fauzan, Pokok-Pokok Hukum Acara Perdata Peradilan Agama dan Mahkamah Syar'iyah di Indonesia, (Jakarta: Kencana, 2005), . 35

14 Abdulkadir Muhammad, Hukum Acara Perdata Indonesia, (Bandung: Citra Aditya Bakti, 2012), . 128. c. Apabila salah satu pihak melakukan sumpah pemutus.

d. Apabila majelis hakim/hakim karena jabatannya dianggap telah mengetahui fakta-faktanya. Maksudnya, Majelis Hakim/Hakim karena jabatannya dianggap telah mnegetahui fakta-fakta tertentu dan kebenaran fakta-fakta ini dianggap telah diketahui oleh Majelis Hakim sehingga pembuktian tidak diperlukan lagi.

Hal ini dapat dilihat dari fakta-fakta prosesuil, yaitu faktafakta yang terjadi selama poses persidangan berjalan dan dilihat sendiri oleh hakim, seperti dalam persidangan para pihak tidak hadir, pengakuan salah satu pihak di persidangan dan lain sebagainya. ${ }^{15}$

\section{Teori-Teori Pembuktian}

Terdapat dua aliran mengenai kekuatan alat bukti:

a. Teori vrijbewijs. Teori ini memberikan kebebasan kepada hakim untuk menilai alat bukti.

b. Teori verplichtbewijs. Teori ini menyatakan bahwa hakim terikat oleh alat-alat bukti. ${ }^{16}$

Adapun ketentuan yang terdapat HIR (Herzien Inlandsch Reglement) menganut gabungan dari teori-teori tersebut, artinya ada ketentuan bahwa hakim terikat dan ada pula yang mengatakan bahwa hakim bebas menilai alat-alat bukti tersebut. Misalnya dalam hal sumpah decisioir hakim terikat oleh sumpah tersebut dan harus dianggap benar oleh hakim. Sedangkan contoh hakim bebas

15 Lilik Mulyadi, Putusan Hakim dalam Hukum Acara Perdata Indonesia, (Bandung: Citra Aditya Bakti, 2009), . 92-93.

${ }^{16}$ Rubini dan Chidir Ali, Pengantar Hukum Acara Perdata, (Bandung: Alumni, 1974), . 86. 
menilai alat bukti yaitu dalam menilai alat bukti saksi. ${ }^{17}$

$\begin{array}{lc}\text { Sudikno } & \begin{array}{c}\text { Mertokusumo } \\ \text { dentang soal } \\ \text { pembuktian }\end{array} \\ \text { penilaian } & \text { pasyid, } \\ \text { mengemukakan } & \text { pendapatnya }\end{array}$ sebagai berikut: "pada umumnya, sepanjang UU tidak mengatur sebaliknya, hakim bebas untuk menilai pembuktian". Berhubung hakim dalam menilai pembuktian dapat bertindak bebas atau diikat oleh UU maka tentang hal tersebut timbul tiga teori, yakni:

a. Teori pembuktian bebas. Teori ini menghendaki seorang hakim bebas dalam menilai alat bukti yang diajukan. Misalnya untuk menilai keterangan saksi, hakim bebas untuk menilainya sebagaimana yang terdapat dalam Pasal 172 HIR atau Pasal 308 RBg dan 1908 KUH Perdata.

b. Teori pembuktian negatif, dalam menilai pembuktian harus ada ketentuanketentuan bersifat negatif yang mengikat dan membatasi hakim dan melarang hakim untuk melakukan sesuatu yang berhubungan dengan pembuktian. Misalnya ketentuan Pasal 169 HIR atau Pasal 306 RBg dan 1906 KUH Perdata bahwa keterangan seorang saksi saja tidak boleh dipercaya oleh hakim (unus testis nullus testis).

c. Teori pembuktian positif, disamping adanya larangan bagi hakim, juga mengharuskan adanya perintah kepada seorang hakim untuk tidak menilai lain selain apa yang dikemukakan

${ }^{17}$ Rubini dan Chidir Ali, Pengantar Hukum Acara Perdata, (Bandung: Alumni, 1974), . 86.

18 Roihan Rasyid, Hukum Acara Peradilan Agama, cet. ke-2, (Jakarta: Rajawali Pres, 1991), . 146. pihak. Misalnya ketentuan Pasal 165 HIR atau Pasal $285 \mathrm{RBg}$ dan Pasal 1870 KUH Perdata, bahwa pembuktian dengan surat akta otentik dianggap bukti yang sempurna yang harus diterima. ${ }^{19}$

\section{Macam-macam Alat Bukti}

Setiap alat bukti yang diajukan di persidangan sah bernilai sebagai alat bukti yang mempunyai nilai kekuatan pembuktian harus mencapai batas minimal. Jika tidak, alat bukti tersebut dikesampingkan dalam penilaian pembuktian. Batas minimal secara teknis dan populer dapat diartikan sebagai suatu jumlah alat bukti yang sah yang paling sedikit harus terpenuhi, agar alat bukti itu mempunyai nilai kekuatan pembuktian untuk mendukung kebenaran yang didalilkan atau dikemukakan. Apabila alat bukti yang diajukan dipersidangan tidak mencapai batas minimal, alat bukti tersebut tidak mempunyai nilai kekuatan pembuktian yang cukup untuk membuktikan kebenaran dalil atau peristiwa maupun pernyataan yang dikemukakan. ${ }^{20}$

$\begin{array}{cc}\text { Adapun } & \text { patokan } \\ \text { menentukan batas minimal }\end{array}$ pembuktian adalah patokan yang didasarkan kualitas tidak kuantitas. Menurut hukum, alat bukti yang berkualitas dan sah sebagai alat bukti adalah alat bukti yang memenuhi syarat formil dan materiil. Untuk mengetahui syarat formil dan syarat materiil apa yang melekat pada suatu alat bukti harus merujuk kepada ketentuan UU yang berkenaan dengan alat bukti yang bersangkutan karena syarat formil dan materiil yang melekat pada

\footnotetext{
${ }^{19}$ Bintania, Hukum Acara........... . 56.

${ }^{20}$ Yahya Harahap, Hukum Acara Perdata,
} cet. Ke-4, (Jakarta: Sinar Grafika, 2006), . 539-540. 
setiap alat bukti tidak sama, misalnya tidak sama syarat formil dan materil alat bukti saksi dengan akta. $^{21}$

Alat bukti dalam hukum acara perdata tertuang dalam Pasal 164 HIR, Pasal 284 RBg, dan Pasal 1866 KUH Perdata yaitu alat bukti surat (tertulis), alat bukti saksi, persangkaan (dugaan), pengakuan dan sumpah. ${ }^{22}$

\section{a. Alat Bukti Surat (Tertulis)}

a) Pengertian alat bukti surat (tertulis)

Alat bukti surat (tertulis) adalah segala sesuatu yang memuat tandatanda bacaan yang dimaksudkan untuk menyampaikan buah fikiran seseorang dan dipergunakan sebagai pembuktian. ${ }^{23}$

b) Macam-macam alat bukti surat (tertulis)

1) Akta, yaitu suatu tulisan yang memang dengan sengaja dibuat untuk dijadikan bukti tentang suatu peristiwa dan ditandatangani. Dengan demikian maka unsurunsur yang penting untuk suatu akta adalah kesengajaan untuk menciptakan suatu alat bukti tertulis dan penandatanganan tulisan itu. $^{24}$

Akta tersebut terbagi dua, yaitu:
(a) Akta
otentik sebagaimana
yang

${ }^{21}$ Harahap, Hukum Acara........... . 542-543.

${ }^{22}$ Erfaniah Zuhriah, Peradilan Agama di Indonesia, Edisi Revisi, (Malang: UIN Malang Press, 2009), . 262.

${ }^{23}$ Rasyid, Hukum Acara........ . 153.

${ }^{24}$ Subekti, Hukum Acara Perdata, cet. ke-2, (Bandung: Bina Cipta, 1982), . 89 disebutkan dalam Pasal 165HIR, Pasal 258 RBg, Pasal 1868 KUH Perdata yaitu akta yang dibuat oleh atau di hadapan pejabat yang berwenang untuk itu menurut ketentuan tertentu yang telah ditetapkan. Akta otentik dibuat "oleh" apabila pejabat yang berwenang tersebut membuat tentang apa yang dilakukannya, misalnya Juru sita Pengadilan membuat berita acara pemanggilan pihakpihak yang berperkara.

Sedangkan dibuat "di hadapan" apabila pejabat yang berwenang tersebut menerangkan apa yang akan dilakukan oleh seseorang dan sekaligus

meletakkannya dalam suatu akta, misalnya A dan B melakukan jual beli, mereka minta untuk dibuatkan akta jualbelinya kepada notaris dan notaris membuatkan akta tersebut di hadapan mereka. ${ }^{25}$

(b) Akta bawah tangan, yaitu segala tulisan yang sengaja dibuat untuk dijadikan bukti tetapi tidak dibuat di hadapan atau oleh pejabat yang

\footnotetext{
${ }^{25}$ Rasyid, Hukum Acara ......... . 153
} 
berwenang untuk itu. Misalnya surat jualbeli tanah yang dibuat oleh ke dua belah pihak. $^{26}$

2) Bukan akta, yaitu tulisan yang tidak sengaja dijadikan alat bukti tentang suatu peristiwa dan/atau tidak ditandatangani oleh pembuatnya. $^{27}$

c) Batas minimal pembuktian alat bukti tulisan

1) Akta otentik. Nilai kekuatan pembuktian akta otentik diatur dalam Pasal 1870 KUH Perdata, Pasal 165 HIR dan Pasal 285 RBg yaitu sempurna dan mengikat. Sempurna berarti tidak memerlukan suatu penambahan pembuktian. Sedangkan mengikat berarti bahwa apa yang ditulis dalam akta tersebut harus dipercaya oleh hakim yaitu harus dianggap benar selama ketidakbenarannya tidak dibuktikan. ${ }^{28}$ Suatu akta otentik, di dalamnya terdapat tiga macam kekuatan. Pertama, membuktikan kepada kedua pihak bahwa mereka telah menerangkan apa yang ditulis dalam akta (kekuatan pembuktian formal). Kedua, membuktikan kepada kedua pihak bahwa peristiwa yang disebutkan dalam akta telah terjadi

${ }^{26}$ Rasyid, Hukum Acara, . 154.

27 Riduan Syahrani, Buku Materi Dasar Hukum Acara Perdata, cet. ke-5 Edisi Revisi, (Bandung: Citra Aditya Bakti, 2009), . 97

${ }^{28}$ Subekti, Hukum Acara........... . 91. (kekuatan pembuktian materil) atau yang dinamakan kekuatan pembuktian "mengikat". Ketiga, membuktikan tidak saja antara para pihak yang bersangkutan tetapi juga pihak ketiga bahwa pada tanggal tersebut dalam akta kedua pihak telah menghadap di muka pegawai umum dan menerangkan apa yang mereka tulis dalam akta tersebut. Kekuatan ketiga ini dinamakan kekuatan pembuktian ke luar. Arti ke luar adalah terhadap pihak ketiga atau dunia luar. $^{29}$

2) Akta bawah tangan mengenai akta bawah tangan tidak diatur dalam HIR, akan tetapi diatur dalam $\mathrm{RBg}$ (Rechtsreglement voor de Buitengewesten). Dengan demikian, perbedaan antara HIR dan RBg adalah kalau HIR hanya mengatur akta otentik, sedangkan $\mathrm{RBg}$ selain mengatur akta otentik juga mengatur akta di bawah tangan. $^{30}$ Menurut Pasal 288 Rbg bahwa sejak tanda tangan diakui, akta di bawah tangan itu memberikan pembuktian yang sama seperti akta otentik yaitu sempurna dan mengikat bagi para pihak yang bersangkutan dan para ahli waris mereka. Akan tetapi, terhadap pihak ketiga akta bawah 
tangan tersebut tidak mengikat karena kekuatan pembuktian ke luar tidak dapat dicapai atau dimiliki oleh suatu akta bawah tangan. $^{31}$

3) Tulisan-tulisan bukan akta HIR dan RBG maupun KUH Perdata tidak mengatur tentang kekuatan pembuktian tulisan-tulisan yang bukan akta. Dengan demikian, tulisan-tulisan yang bukan akta adalah sebagai alat bukti bebas, artinya hakim mempunyai kebebasan untuk mempercayai atau tidak mempercayai tulisantulisan yang bukan akta tersebut. $^{32}$

\section{b. Alat Bukti dengan Saksi}

a) Pengertian kesaksian

Kesaksian yaitu alat bukti yang diberitahukan secara lisan dan pribadi oleh saksi yang tidak $m$ pihak dalam perkara tersebut, untuk memberikan kepastian kepada hakim di muka persidangan tentang peristiwa yang dipersengketakan. Dengan demikian, unsur yang harus ada pada alat bukti kesaksian adalah:

1) Keterangan kesaksian itu diucapkan sendiri oleh saksi secara lisan di muka persidangan.

2) Tujuan kesaksian untuk memberi kepastian kepada hakim tentang peristiwa yang dipersengketakan.
3) Saksi tidak merupakan salah satu pihak yang berperkara. ${ }^{33}$

b) Macam-macam saksi

1) Saksi yang telah memenuhi kriteria sebagai alat bukti, yakni saksi yang terdiri dari dua orang yang telah memenuhi syarat formil dan materiil.

2) Saksi yang hanya satu orang (unus testis nullus testis). Hakim diperkenankan untuk menganggap satu peristiwa terbukti dari keterangan seorang saksi. Larangan untuk mempercayai keterangan seorang saksi sebagaimana yang dimaksud Pasal 169 HIR yang menyatakan bahwa keterangan seorang saksi tanpa ada alat bukti lain tidak dapat dipercaya dimaksudkan sebagai suatu larangan untuk mengabulkan suatu gugatan apabila dalil-dalil penggugat disangkal dan hanya dikuatkan oleh satu orang saksi saja. ${ }^{34}$

3) Saksi testimonium de auditu, yaitu saksi yang memberikan keterangan dari apa yang didengarnya dari orang lain. Saksi testimonium de auditu memang tidak ada artinya, akan tetapi hakim tidak dilarang untuk menerimanya, yang dilarang adalah apabila saksi tersebut menarik kesimpulan atau menurut istilah Pasal 171 (2) HIR

\footnotetext{
${ }^{31}$ Subekti, Hukum Acara.............. . 94.

${ }^{32}$ Syhrani, Buku Materi 98
}

\footnotetext{
${ }^{33}$ Ali, Asas-Asas Hukum........... . 92.

${ }^{34}$ Subekti, Hukum Acara.......... . 105
} 
atau Pasal 308 (2) RGB

memberikan "pendapat

atau

perkiraan". 35

c) Kekuatan pembuktian dengan alat bukti saksi

Mengenai kekuatan pembuktian keterangan saksi, berdasarkan Pasal 1908 KUH Perdata dan Pasal 172 HIR bersifat bebas. Menurut pasal tersebut, hakim bebas mempertimbangkan atau menilai keterangan saksi berdasar kesamaan atau saling berhubugannya antara saksi yang satu dengan yang lain. Maksud pengertian nilai kekuatan pembuktian bebas yang melekat pada alat bukti saksi adalah kebenaran yang terkandung dalam keterangan yang diberikan saksi di persidangan dianggap tidak sempurna dan tidak mengikat dan hakim tidak terikat untuk menerima atau menolak kebenarannya. ${ }^{36}$

Bertitik tolak dari nilai kekuatan pembuktian yang bersifat bebas, maka batas minimal pembuktian dengan alat bukti saksi yaitu saksi paling sedikit 2 (dua) orang yang telah memenuhi syarat formil dan materiil. Dengan demikian, satu orang saksi saja belum mencapai batas minimal pembuktian karena seorang saksi tidak merupakan kesaksian (unus testis nullus testis). Akan tetapi, apabila alat bukti seorang saksi dikuatkan dengan satu alat bukti lain serta keterangan saksi sesuai

\footnotetext{
${ }^{35}$ Subekti, Hukum Acara........ . 106

${ }^{36}$ Harahap, Hukum Acara...... . 548
}

dengan alat bukti lain, maka hakim dapat memberikan putusan berdasarkan kedua alat bukti tersebut. ${ }^{37}$

\section{c. Persangkaan}

a) Pengertian persangkaan

Persangkaan adalah bukti kesimpulan oleh UU atau hakim yang ditarik dari peristiwa yang terkenal ke arah suatu peristiwa yang tidak terkenal. Sedangkan Pitlo berpendapat bahwa persangkaan adalah uraian hakim, dengan mana hakim dari fakta yang terbukti menyimpulkan fakta yang tidak terbukti. $^{38}$

b) Macam-macam persangkaan Persangkaan menurut hakim adalah kesimpulan hakim yang ditarik atau sebagai hasil dari pemeriksaan sidang. Pengertian persangkaan menurut hakim sesungguhnya amat luas. Segala peristiwa, keadaan dalam sidang, bahanbahan yang didapat dari pemeriksaan perkara tersebut dapat dijadikan bahan untuk menyusun persangkaan hakim. ${ }^{39}$

Persangkaan menurut UU adalah persangkaan berdasarkan suatu ketentuan khusus UU yang dihubungkan dengan perbuatan atau peristiwa

\footnotetext{
${ }^{37}$ Harahap, Hukum Acara.......... . 548-549.
}

38 Wahju Muljono, Teori dan Praktik Peradilan Perdata di Indonesia, (Yogyakarta: Pustaka Yustisia, 2012), . 114

39 Retnowulan Sutantio dan Iskandar Oeripkartawinata, Hukum Acara Perdata dalam Teori dan Praktek, cet. ke-11, (Bandung: Mandar Maju, 2009), . 78. 
tertentu. $^{40} \quad$ Persangkaan menurut UU dibagi atas dua jenis yaitu yang masih memungkinkan pembuktian lawan dan yang tidak memungkinkan pembuktian lawan. ${ }^{41}$

c) Kekuatan pembuktian alat bukti persangkaan

Persangkaan menurut hakim mempunyai nilai kekuatan pembuktian yang bersifat bebas. Oleh karena itu, hakim bebas untuk menerima atau menolak kebenaran yang terdapat di dalam persangkaan tersebut. Dengan demikian, karena nilai kekuatan pembuktiannya bebas maka persangkaan menurut hakim tidak dapat berdiri sendiri, minimal harus ada dua persangkaan atau satu persangkaan dikuatkan dengan satu alat bukti lain. ${ }^{42}$

Persangkaan menurut UU yang tidak memungkinkan pembuktian lawan, maka nilai kekuatan pembuktiannya bersifat sempurna, mengikat dan memaksa. Dengan demikian, kebenaran yang melekat pada alat bukti ini bersifat imperatif bagi hakim untuk dijadikan sebagai dasar penilaian dalam mengambil putusan. Oleh karena pada alat bukti ini melekat nilai kekuatan pembuktian yang sempurna, mengikat dan menentukan, maka alat bukti tersebut dapat berdiri sendiri tanpa bantuan alat bukti lain dan telah memenuhi batas minimal pembuktian. ${ }^{43}$

Adapun persangkaan menurut UU yang memungkinkan pembuktian lawan, maka nilai pembuktiannya tidak absolut karena dapat dibantah dengan bukti lawan. Dengan demikian, nilai kekuatan pembuktian alat bukti ini menjadi alat bukti permulaan dan tidak dapat berdiri sendiri tetapi harus mendapat dukungan alat bukti lain agar dapat mencapai batas minimal pembuktian. ${ }^{44}$

\section{d. Pengakuan}

a) Pengertian pengakuan

Pengertian pengakuan yaitu suatu pernyataan dengan bentuk tertulis atau lisan dari salah satu pihak beperkara yang isinya membenarkan dalil lawan baik sebagian maupun seluruhnya. ${ }^{45}$

b) Macam-macam pengakuan

1) Pengakuan murni yaitu pengakuan yang membenarkan secara keseluruhan gugatan penggugat.

2) Pengakuan dengan kualifikasi yaitu pengakuan yang disertai dengan keterangan tambahan sangkalan dari pihak lawan.

3) Pengakuan dengan klausul yaitu yang disertai dengan keterangan tambahan yang sifatnya

dapat

40 Sophar Maru Hutagalung, Praktik Peradilan Perdata, cet. ke-2, (Jakarta: Sinar Grafika, 2011), . 86.

${ }^{41}$ Ali, Asas-Asas Hukum............ . 94.

${ }^{42}$ Harahap, Hukum Acara....... . 552.

\footnotetext{
${ }^{43}$ Harahap, Hukum Acara....... . 551

${ }^{44}$ Harahap, Hukum Acara....... . 552.

${ }^{45}$ Hutagalung, Praktik Peradilan.. 87.
} 
membebaskan diri dari
gugatan.

c) Kekuatan pembuktian alat bukti pengakuan

1) Pengakuan murni yang telah memenuhi syarat formil dan meteriil, nilai kekuatan pembuktiannya bersifat sempurna, mengikat dan menentukan. Dengan demikian, kebenaran yang terkandung dalam pengakuan murni merupakan kekuatan yang bersifat mutlak sehingga para pihak dan hakim terikat untuk menerima kebenaran tersebut dan hakim harus mempergunakannya sebagai dasar penyelesaian. $^{47}$ Syarat formil pengakuan yaitu disampaikan dalam proses persidangan dan pengakuan diberikan oleh pihak materil/kuasanya dalam bentuk lisan atau tertulis dalam replikduplik atau kesimpulan. Sedangkan syarat materil pengakuan yaitu pengakuan berhubungan langsung dengan pokok perkara, tidak bertentangan dengan hukum, susila, agama dan ketertiban umum serta tidak merupakan kebohongan. ${ }^{48}$

46 Sarwono, Hukum Acara Perdata dalam Teori dan Praktik, cet. ke-2, (Jakarta: Sinar Grafika, 2011), . 277-278.

${ }^{47}$ Harahap, Hukum Acara....... . 549.

48 Chatib Rasyid dan Syaifuddin, Hukum Acara Perdata dalam Teori dan Praktik pada
2) Pengakuan dengan

klausula dan kualifikasi

Adapun pengakuan

dengan klausula dan pengakuan dengan klasifikasi dalam praktik tidak begitu mudah membedakan antara keduanya sehingga yang sering diterapkan adalah pengakuan dengan klausula meskipun yang sebenarnya terjadi secara teoritis adalah pengakuan dengan kualifikasi. ${ }^{49}$

Pengakuan dengan klausul harus ditegakkan prinsip tidak boleh dipecah. Hakim tidak boleh menerima sebagian yang menguntungkan pihak lain dan menolak pengakuan yang merugikan pihak yang mengaku, tetapi pengakuan tersebut harus diterima secara keseluruhan

dipertimbangkan oleh hakim dengan seksama. Dengan demikian, nilai pembuktiannya bersifat bebas bahkan sifat kekuatan pembuktiannya hanya sebagai alat bukti permulaan. Oleh karena sifat kekuatan pembuktiannya sebagai alat bukti permulaan, maka batas minimal pembuktiannya harus dikuatkan dengan satu alat bukti lain. $^{50}$

\section{e. Sumpah}

Peradilan Agama, (Yogyakarta: UII Press, 2009), . 113

\footnotetext{
${ }^{49}$ Harahap, Hukum Acara........ . 738.

${ }^{50}$ Harahap, Hukum Acara.......... 550-551.
} 
a) Pengertian sumpah

Sumpah adalah suatu pernyataan khidmat yang diberikan atau diucapkan pada waktu memberi janji atau keterangan dengan mengingat akan sifat Maha kuasa Tuhan dan percaya bahwa siapa yang memberi keterangan atau janji yang tidak benar akan dihukum oleh-Nya. Jadi pada hakikatnya sumpah merupakan tindakan bersifat religius yang digunakan dalam peradilan. ${ }^{51}$

b) Macam-macam sumpah

1) Sumpah decisoir (sumpah pemutus), adalah sumpah yang dibebankan atas permintaan salah satu pihak kepada lawannya yang bertujuan untuk menyelesaikan suatu perkara. $^{52}$

2) Sumpah supletoir (sumpah pelengkap), adalah sumpah yang diperintahkan oleh hakim karena jabatannya kepada salah satu pihak yang berperkara untuk menambah (melengkapi) pembuktian peristiwa yang belum lengkap. Dengan demikian, sumpah penambah hanya dapat diperintahkan oleh hakim kepada salah satu pihak yang berperkara apabila telah ada alat bukti permulaan, tetapi masih belum mencukupi dan tidak ada alat bukti lain.
Permulaan pembuktian ini berbagai macam bentuknya, dapat berupa satu orang saksi, tulisan yang bukan akta atau hanya ada pengakuan di luar sidang pengadilan dan sebagainya. Apabila tidak ada alat bukti maka hakim tidak boleh memerintahkan salah satu pihak yang berperkara untuk mengangkat sumpah tambahan, demikian pula apabila sudah ada alat bukti telah mencapai batas minimal pembuktian. ${ }^{53}$

3) Sumpah aestimatoir (sumpah penaksiran), adalah sumpah yang diperintahkan oleh hakim karena jabatannya kepada penggugat untuk menentukan jumlah uang ganti rugi yang dituntutnya. Sumpah ini dibebankan oleh hakim kepada penggugat apabila penggugat telah berhasil membuktikan haknya atas ganti kerugian akan tetapi jumlahnya tidak jelas. ${ }^{54}$

c) Kekuatan pembuktian alat bukti sumpah

1) Sumpah decisoir (pemutus) mempunyai kekuatan pembuktian yang menentukan dan secara mutlak dapat berdiri sendiri tanpa bantuan alat bukti lain sehingga tidak memungkinkan adanya pembuktian lawan. ${ }^{55} \mathrm{Hal}$ ini disebabkan karena UU telah menentukan apabila
${ }^{51}$ Mertokusumo, Hukum Acara......... . 197.

52 Abdulkadir Muhammad, Hukum Acara Perdata Indonesia, (Bandung: Citra Aditya Bakti, 2012), . 156.

\footnotetext{
${ }^{53}$ Syahrani, Buku Materi...... 116-117.

${ }^{54}$ Ali, Asas-Asas Hukum 97.

${ }^{55}$ Ali, Asas-Asas Hukum. .96.
} 


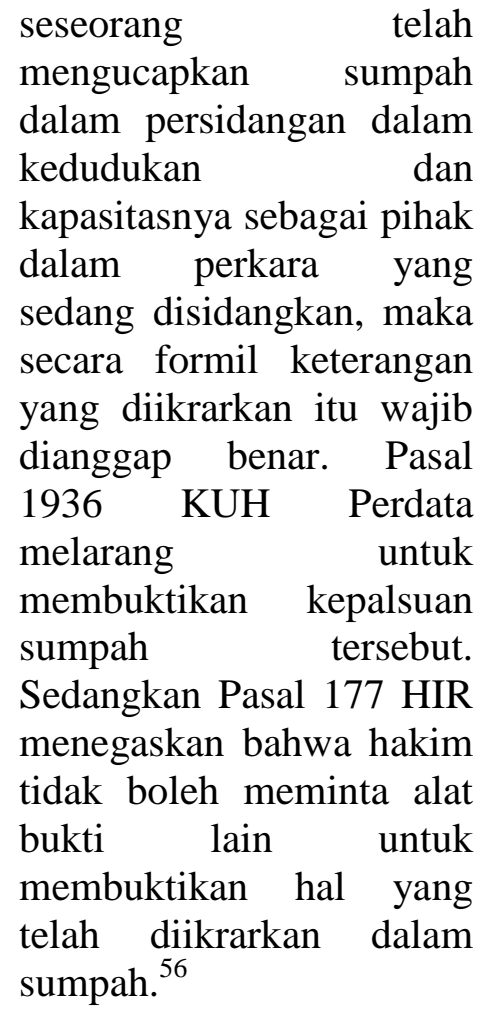

2) Sumpah supletoir (pelengkap) mempunyai nilai kekuatan pembuktian yang sama dengan sumpah pemutus, yakni bersifat sempurna, mengikat dan memaksa sehingga hakim secara mutlak terikat menerima kebenarannya dan putusan yang dijatuhkan bertitik tolak dari alat bukti tersebut. Akan tetapi, ada yang berpendapat bahwa sumpah pelengkap ini hanya mempunyai nilai kekuatan penyempurna dan pengikat sehingga terhadapnya dapat diajukan bukti lawan apabila pihak lawan dapat membuktikan bahwa sumpah tersebut palsu. ${ }^{57}$

3) Sumpah aestimatoir (penaksir), nilai kekuatan pembuktian sumpah penaksir oleh M. Yahya Harahap disebut sempurna, mengikat dan menentukan. Kekuatan pembuktian sumpah penaksir ini disebutkan dalam Pasal 314 RBg/Pasal 177 HIR/ 1936 KUH Perdata sebagai pembuktian yang tidak boleh dimintakan bukti lain untuk menguatkan apa yang telah diucapkannya. Namun demikian, menurut Sudikno Mertokusumo kekuatan pembuktian sumpah penaksir sama dengan sumpah tambahan, yaitu bersifat sempurna dan memungkinkan pembuktian lawan. ${ }^{58}$

\section{Tata Cara dan Persyaratan Pembuktian dengan Alat Bukti Saksi}

Saksi ialah orang yang memberi keterangan di muka sidang tentang suatu peristiwa atau keadaan yang ia lihat, ia dengar, dan ia alami sendiri. Sedangkan kesaksian adalah kepastian yang diberikan kepada hakim tentang peristiwa yang disengketakan dengan jalan pemberitahuan secara lisan dan pribadi oleh seseorang yang tidak merupakan salah satu dari pihak yang berperkara yang dipanggil di persidangan. ${ }^{59}$

$$
\text { Penunjukkan saksi }
$$
dilakukan oleh pihak yang berkepentingan atau oleh hakim karena jabatannya yang diperlukan untuk menyelesaikan perkara. Para pihak dapat mengajukan pertanyaan kepada saksi melalui Majelis Hakim tentang hal-hal yang

\footnotetext{
${ }^{58}$ Rasyid, Hukum Acara...... . 116.

${ }^{59}$ Bintania, Hukum Acara..... . 58.
} ${ }^{56}$ Harahap, Hukum Acara......... . 746.
${ }^{57}$ Harahap, Hukum Acara......... 778. 
dianggap penting. Hakim menimbang relevansi pertanyaan dengan perkara apabila relevan, hakim dapat meneruskan pertanyaan kepada saksi dan apabila tidak relevan, tidak perlu ditanyakan. Hakim dapat bertanya kepada saksi untuk mendapatkan kebenaran. Saksi yang telah diperiksa tetap duduk dalam ruang sidang agar ia tidak saling berhubungan dengan saksi-saksi lain dan agar tidak sulit apabila diperlukan keterangan tambahan atau konfirmasi. ${ }^{60}$

Saksi sebagai salah satu alat bukti harus memenuhi syarat formil dan materiil alat bukti saksi serta telah mencapai batas minimal pembuktian. Syarat formil alat bukti saksi yaitu saksi tidak orang yang dilarang untuk menjadi saksi, memberikan keterangan di persidangan, mengucapkan sumpah menurut agama atau keyakinannya dan diperiksa satu persatu. Adapun syarat materiil alat bukti saksi yaitu keterangan yang diberikan didukung oleh alasan dan pengetahuan, fakta peristiwa yang diterangkan bersumber dari pengalaman, penglihatan dan pendengaran sendiri tentang hal yang benar-benar berkaitan langsung dengan perkara dan keterangan yang diberikan sesuai antara saksi yang satu dengan yang saksi lain atau alat bukti lain. ${ }^{61}$

Saksi agar dapat mencapai batas minimal pembuktian harus berjumlah dua orang atau lebih. Keterangan dengan satu orang saksi dengan tidak ada alat bukti lain di dalam hukum tidak dapat

60 Mukti Arto, Praktek Perkara Perdata pada Pengadilan Agama, (Yogyakarta: Pustaka Pelajar, 1996), . 164.

${ }^{61}$ Harahap, Hukum Acara........ . 543. dipercaya. Kesaksian yang berbeda dan tersendiri dari beberapa orang tentang beberapa kejadian dapat menguatkan suatu perkara tertentu. Oleh karena kesaksian tersebut bersesuaian dan berhubungan maka penilaiannya diserahkan kepada hakim. ${ }^{62}$

Sebagaimana yang telah disebutkan bahwa syarat formil alat bukti saksi salah satunya adalah saksi tidak orang yang dilarang untuk menjadi saksi. Adapun orang yang dilarang menjadi saksi sebagaimana yang diatur dalam Pasal 145 (1) HIR atau Pasal 172 (1) RBg yaitu saksi yang berasal keluarga sedarah dan keluarga semenda secara garis lurus, suami/isteri dari pihak meskipun telah bercerai, anak di bawah umur 15 tahun dan orang gila meskipun terkadang sembuh. $^{63}$

Keluarga sedarah atau semenda dilarang menjadi saksi sebagaimana yang ditegaskan dalam Pasal 145 (1) HIR atau Pasal 172 (1) RBg karena dikhawatirkan mereka akan memberikan keterangan palsu di persidangan disebabkan hubungan keluarga yang dekat. Anak-anak yang belum mencapai umur 15 tahun dilarang untuk didengar sebagai saksi kecuali apabila mereka telah menikah karena mereka dikhawatirkan mengkhayal dan keterangan mereka belum dapat dipertanggungjawabkan.

Sedangkan orang gila dilarang menjadi saksi karena keterangan mereka tidak dapat dipertanggungjawabkan. ${ }^{64}$

${ }^{62}$ Bintania, Hukum Acara........ . 60. R. Soesilo, RIB/HIR dengan Penjelasannya, (Bogor: Politeia, 1995), . 105

${ }^{64}$ Sutantio, Hukum Acara........ . 72. 
Aturan mengenai pembuktian dengan alat bukti saksi di Pengadilan Agama secara umum mengikuti aturan yang berlaku untuk pembuktian dengan saksi di lingkungan Peradilan Umum sebagaimana yang disebutkan dalam UU Peradilan Agama Pasal 54 yaitu: "Hukum Acara yang berlaku pada Pengadilan dalam lingkungan Peradilan Agama adalah Hukum Acara Perdata yang berlaku pada Pengadilan dalam lingkungan Peradilan Umum kecuali yang telah diatur secara khusus dalam UU ini". ${ }^{65}$

Di samping itu, terdapat aturan hukum acara khusus mengenai pembuktian dengan saksi seperti dalam sengketa perceraian. Dalam sengketa perkawinan, untuk mendapatkan putusan perceraian dengan alasan percekcokan (syiqaq) dan tidak ada harapan akan hidup rukun dalam berumah tangga lagi, maka harus didengar keterangan saksi dari keluarga atau orang-orang yang dekat dengan suami istri. Dengan demikian, ketentuan yang menyatakan bahwa orang yang memiliki hubungan darah dan semenda tidak boleh menjadi saksi, dikesampingkan oleh Pasal 76 (1) UU No. 7 Tahun 1989 jo. UU No. 3 Tahun 2006 jo. UU No. 50 Tahun 2009 tentang Peradilan Agama. ${ }^{66}$

Dalam perkara tertentu saksi yang berasal dari keluarga sedarah atau semenda dapat diterima dalam perkara:

a. Perkara-perkara mengenai kedudukan keperdataan salah

${ }^{65}$ Pasal 54 UU No. 7 Tahun 1989 jo. UU No. 3 Tahun 2006 jo. UU No. 50 Tahun 2009 tentang Peradilan Agama

${ }^{66}$ Bintania, Hukum Acara....... . 63. satu pihak yang digariskan Pasal 145 (2) HIR.

b. Perkara-perkara mengenai nafkah yang harus dibayar, meliputi pembiayaan pemeliharaan, dan pendidikan yang digariskan Pasal 141 UU No. 1 tahun 1974 tentang Perkawinan jo. Pasal 24 PP No.9 Tahun 1975.

c. Perkara-perkara mengenai alasan yang dapat menyebabkan pembebasan atau pemecatan dari kekuasaan orang tua berdasar Pasal 214 KUH Perdata dan Pasal 49 UU No. 1 Tahun 1974 tentang Perkawinan.

d. Perkara mengenai suatu persetujuan perburuhan yang digariskan Pasal 145 (2) HIR. ${ }^{67}$

Keluarga sedarah dan semenda tidak dapat ditolak kesaksiannya sebagaimana yang disebutkan dalam Pasal 145 (2) HIR atau Pasal 172 (2) RBg yakni dalam perkara perselisihan kedua belah pihak tentang keadaan menurut hukum perdata atau tentang suatu perjanjian pekerjaan. Yang dimaksud dengan kedudukan perdata ialah mengenai hal ihwal pribadi seseorang yang ditentukan dalam hukum perdata, misalnya tentang kelahiran, keturunan, kematian, perkawinan dan perceraian. $^{68}$

Persoalan pembuktian dengan saksi di pengadilan harus dibedakan antara saksi sebagai syarat hukum dengan saksi sebagai alat pembuktian karena fungsi keduanya sangat berbeda, misalnya sebagai syarat hukum sahnya nikah harus disaksikan minimal dua orang

${ }^{67}$ Harahap, Hukum Acara....... . 634.

68 Taufik Makarao, Pokok-Pokok Hukum Acara Perdata, (Jakarta: Rineka Cipta, 2004), . 106. 
saksi tetapi untuk membuktikan sahnya perkawinan tidak harus dengan dua orang saksi. Pembuktian dapat berupa pengakuan suami istri, sumpah, akta nikah dan lain-lain. ${ }^{69}$

Kesaksian yang telah memenuhi syarat formil maupun materil mempunyai nilai pembuktian bebas. Nilai kebenaran kesaksian sifatnya tidak sempurna dan tidak mengikat baik kepada pihak-pihak maupun terhadap hakim. Hakim bebas menilai kebenaran keterangan saksi dan dapat mengesampingkan keterangan saksi asal dipertimbangkan dengan cukup dan berdasarkan argumentasi yang kuat. Dalam pemeriksaan para saksi, hakim tidak boleh menerima suatu hal sebagai kenyataan yang dikemukakan oleh saksi selama belum yakin tentang kebenaran yang disampaikan oleh saksi. ${ }^{70}$

Menurut M. Yahya Harahap, alat bukti saksi yang terdiri dari dua orang dan keduanya memenuhi syarat formil dan materiil, maka dianggap cukup memenuhi batas minimal pembuktian. Oleh karena itu, tidak diperlukan bantuan atau tambahan alat bukti lain karena sesuai dengan ketentuan Pasal 169 HIR. Pasal 1911 KUH Perdata, keharusan melakukan penambahan alat bukti lain apabila saksi yang diajukan hanya terdiri dari satu saksi saja (unus testis). ${ }^{71}$

\section{Kesimpilan}

Pembuktian adalah tahap yang memiliki peranan penting bagi hakim untuk menjatuhkan putusan. Proses pembuktian dalam proses persidangan

\footnotetext{
${ }^{69}$ Rasyid, Hukum Acara...... . 156.

${ }^{70}$ Bintania, Hukum Acara...... . 68.

${ }^{71}$ Harahap, Hukum Acara...... . 650.
}

dapat dikatakan sebagai sentral dari proses pemeriksaan di pengadilan. Pembuktian menjadi sentral karena dalil-dalil para pihak diuji melalui tahap pembuktian guna menemukan hukum yang akan diterapkan (rechtoepasing) maupun ditemukan (rechtvinding) dalam suatu perkara tertentu.

Tujuan dari pembuktian adalah untuk menetapkan hubungan hukum antara kedua belah pihak yang berperkara dipengadilan untuk dapat memberi kepastian dan keyakinan kepada hakim atas dalil yang disertai alat bukti yang diajukan di pengadilan, pada tahap ini hakim dapat mempertimbangkan putusan perkara yang dapat memberikan suatu kebenaran yang memiliki nilai kepastian hukum dan keadilan.

\section{DAFTAR PUSTAKA}

Ali, Achmad dan Wiwie Heryani, AsasAsas Hukum Pembuktian Perdata, Jakarta: Kencana, 2012

Andrisman, Tri, Hukum Acara Pidana, Bandarlampung: Penerbit Universitas Lampung, 2010

Arto, Mukti, Praktek Perkara Perdata pada Pengadilan Agama, Yogyakarta: Pustaka Pelajar, 1996

Bintania, Aris, Hukum Acara Peradilan Agama dalam Kerangka Fiqh al-Qadha, Jakarta: Raja Grafindo Persada, 2012

Fauzan, M. Pokok-Pokok Hukum Acara Perdata Peradilan Agama dan Mahkamah Syar'iyah di Indonesia, Jakarta: Kencana, 2005

Hamzah, Andi, Hukum Acara Pidana Indonesia, Jakarta: Sinar Grafika, 2008 Kamus Hukum, Jakarta: Ghalia, 2006 
Harahap, Yahya, Hukum Acara Perdata, cet. Ke-4, Jakarta: Sinar Grafika, 2006

Pembahasan

Permasalahan dan Penerapan KUHAP, Jilid 2, Jakarta: Sinar Grafika, 1993

Makarao, Taufik, Pokok-Pokok Hukum Acara Perdata, Jakarta: Rineka Cipta, 2004

Manan, Abdul, Penerapan Hukum Acara Perdata di Lingkungan Peradilan Agama, cet. ke-5, Jakarta: Kencana, 2008

Maru Hutagalung, Sophar, Praktik Peradilan Perdata, cet. ke-2, Jakarta: Sinar Grafika, 2011

Mertokusumo, Sudikno, Hukum Acara Perdata Indonesia, Edisi Revisi, Yogyakarta: Cahaya Atma Pustaka, 2013

Muhammad, Abdulkadir, Hukum Acara Perdata Indonesia, Bandung: Citra Aditya Bakti, 2012

Muljono, Wahju, Teori dan Praktik Peradilan Perdata di Indonesia, Yogyakarta: Pustaka Yustisia, 2012

Mulyadi, Lilik, Putusan Hakim dalam Hukum Acara Perdata Indonesia, Bandung: Citra Aditya Bakti, 2009

R. Soesilo, RIB/HIR dengan Penjelasannya, (Bogor: Politeia, 1995

Rasyid, Chatib dan Syaifuddin, Hukum Acara Perdata dalam Teori dan Praktik pada Peradilan Agama, Yogyakarta: UII Press, 2009

Rasyid, Roihan A, Hukum Acara Peradilan Agama, Jakarta: Raja Grafindo Persada, 2006

Rubini dan Chidir Ali, Pengantar Hukum Acara Perdata, Bandung: Alumni, 1974

Sarwono, Hukum Acara Perdata dalam Teori dan Praktik, cet. ke-2, Jakarta: Sinar Grafika, 2011
Sasangka, Hari dan Lily Rosita, Hukum Pembuktian dalam Perkara Pidana, Bandung, Mandar Maju, 2003

Subekti, Hukum Acara Perdata, cet. ke-2, Bandung: Bina Cipta, 1982

Sutantio, Retnowulan dan Iskandar Oeripkartawinata, Hukum Acara Perdata dalam Teori dan Praktek, cet. ke-11, Bandung: Mandar Maju, 2009

Syahrani, Riduan, Buku Materi Dasar Hukum Acara Perdata, cet. ke5 Edisi Revisi, Bandung: Citra Aditya Bakti, 2009

Zuhriah, Erfaniah, Peradilan Agama di Indonesia, Edisi Revisi, Malang: UIN Malang Press, 2009 